\title{
The Impact of Political Leadership and Corruption on Nigeria's Development since Independence
}

\author{
Olu Awofeso ${ }^{1} \&$ Temitayo Isaac Odeyemi ${ }^{1}$ \\ ${ }^{1}$ Department of Political Science, Obafemi Awolowo University, Ile-Ife, Nigeria \\ Correspondence: T. I. Odeyemi, Department of Political Science, Obafemi Awolowo University, Ile-Ife, Nigeria. \\ Tel: 234-70-6526-0752; 234-80-2393-0309. E-mail: olufeso2012@yahoo.com; odeyemiisaac11@gmail.com
}

Received: August 13, 2014

Accepted: September 5, 2014 Online Published: September 28, 2014

doi:10.5539/jsd.v7n5p240

URL: http://dx.doi.org/10.5539/jsd.v7n5p240

\begin{abstract}
The paper draws an interlocking relationship between political leadership and development and concludes that, while leadership had played tremendous role in the socio-political and economic development of most nations of the world, the reverse is the case in Nigeria. Apart from identifying other social vices that accounted for the protracted state of Nigeria's underdevelopment, the paper also singles out corruption as the major impediment to Nigeria's quest for development since independence. Drawing from the World Bank, Transparency International and highly knowledgeable scholars in this field, the paper demonstrates the process through which Nigerian political leadership became 'neck-deep' in corruption with several cases of monumeotal diversion of public funds meant for the economic development of the country into individual pockets. The multi-dimensional consequences of corrupt practices on a nation's socio-political and economic development cannot be overemphasised, as virtually all sectors of the country, including education, health, agriculture, politics, technology, e.t.c, are negatively affected, with the resultant outcome like extreme poverty, high level of illiteracy, economic dependency, technological backwardness, political instability, e.t.c, as the order of the day. Nigeria's situation typifies the above as shown in the paper.
\end{abstract}

Keywords: political leadership, corruption, poverty, development, politics

\section{Introduction}

The concepts of "corruption", "leadership" and "development" have attained important usage in the lexicon of third world countries of the world - situated mainly in Africa, Asia and Latin America. They have become important concepts that tend to explain how some countries of the world, through constituted authorities, are utilising the resources at their disposal to attain their desired societal ends and bolster the capacity of citizens, while also attempting to overcome structural obstacles to such desirable ends. Nigeria with its vast endowment of human and material resources feature prominently in this list. Following the attainment of political independence in October 1960, the country exuded bright prospects of development potentials that could lead Africa, nay the newly decolonised nations, on the path of socio-economic and material wellbeing of the citizenry.

Despite the huge promise of development capability and an enormous array of resources, the Nigerian economy has witnessed a period of stagnant economic growth (Dahida \& Akangbe, 2013). This has been partly blamed on corruption and gross mismanagement of the country's vast resources. The country has witnessed a depletion of its material resources for private benefit, buttressed by unmitigated levels of personal aggrandisement and self-glorification on the part of leaders at various levels. It begs the question, that despite her position as number eight in the list of countries that export crude oil into the international market, more than 70 percent of the Nigerian population are still classified as poor (Ogbeidi, 2012).

The importance of leadership in charting development ends of the state becomes glaring when one considers the fact that arguably has any nation of the world escaped the dreaded doldrums of underdevelopment across different sectors without enjoying some level of committed, visionary and focused leadership imbued with well laid out and strategic development master plan. This underscores the prominence of good governance in the pursuit of sustainable development ends.

The situation in Nigeria has however been that the country has not been able to implement policies which promote good governance and facilitate development due to the prevalent existence of both high (political) and 
low levels (bureaucratic) corruption (Dahida \& Akangbe, 2013). All these have resulted into what Bassey, et al (2013) refers to as "the tragic story of Nigerian retrogression since its political independence" with deep concerns that in the midst of abundant resources, favourable climate and stupendous wealth from oil, the country has made little or no substantial progress in development, with ills such as stagnation, underdevelopment, leadership and succession crises ravaging the polity (Bassey et al., 2013; Fagbadebo, 2007; Odeyemi, 2014).

It then becomes imperative to interrogate how leadership activities in Nigeria has influenced the current development challenge across sectors and political divisions of the country, vis a vis the harmful outcome of corrupt practices on governance, public utilities, resource endowment and how they affect development in the social, economic, institutional and political realm.

Attempt is made to assess the impact of the phenomenon of corruption on the wellbeing of the country as a whole. Argument is made that from the outset of independence attainment, successive sets of the nation's political leaders and decision makers at all levels of public life have institutionalised corrupt acts and abusive behaviour in Nigeria, and have thus severely constrained the nation's development potentials. Following this introductory section, the concepts of corruption, leadership and development are discussed in different strands. A trace is then made of the challenge of corruption in Nigeria and amongst Nigerians. An appraisal of the current Goodluck Jonathan administration with respect to corrupt acts is made and a synopsis of leaders and corrupt acts relating to governance and affecting development precedes summary and conclusion.

\section{On Corruption, Leadership and Underdevelopment}

Like it happens across the multidisciplinary fields of the social sciences, there exists various conceptions of corruption, leadership and development/underdevelopment. We shall however consider a few of these viewpoints.

Corruption is a word that has been defined differently by both practitioners and academicians who study it, depending largely on the individual's cultural background, discipline and political leaning. However, the word corruption may be used to explain acts that mean abuse of public office for private gain (Dahida and Akangbe, 2013). It becomes glaring when a public official experiences a conflict of interest in scenarios of having to exercise the powers of public office in the public interest on the one hand, and personal interest in attaining private gain on the other hand. Corrupt acts then imply exploiting one's public position, the commonwealth and power for personal benefits.

The World Bank offers a broader platform to examine the notion of corruption as:

... cover(ing) a broad range of human actions. . (it is) the abuse of public office for private gain. Public office is abused for private gain when an official accepts, solicits, or extorts a bribe. It is also abused when private agents actively offer bribes to circumvent public policies and processes for competitive advantage and profit. Public office can also be abused for personal benefit even if no bribery occurs, through patronage and nepotism, the theft of state assets, or the diversion of state revenues. Like most other definitions, it places the public sector at the center of the phenomenon. This should not be taken to mean that corruption cannot occur or that its effects are minor in private sector activities. (World Bank, 1999)

The public-private sphere analysis captured in the World Bank view is accentuated in the opinion of Yagboyaju (2011) who sees corruption as "any anti-social behaviour or illegal act, which involves inducement or undue influence of people either in the public setting or the private sphere to act contrary to the extant rules and regulations which normally guide a particular process". Its meaning is summarised in anti-social behaviours such as fraudulent acts, theft, embezzlement (misappropriation of non-private resources) and bribery (payments aimed at attaining a benefit or escaping a bad outcome).

One can also view corruption from its various ways of manifesting. In this realm, scholars have offered similar views. Yagboyaju (2011) categorised it into economic, bureaucratic and political corruption, in which all are different manifestations of the same phenomenon. The author opines that political corruption in all its ways of manifesting has the most telling and cataclysmic effects on democracy and good governance in most modern societies. To this, the World Bank (1999) adds that corrupt acts in public life happen at both the political and the bureaucratic levels, with the former possessing the potential of being independent of the latter, or both may happen collusively.

Ovienloba (2007) explains the different forms of corruption to include systematic or bureaucratic corruption and endemic corruption. He argues that systematic corruption occurs in the public sector and it is also referred to as 
bureaucratic corruption. This kind of corruption frustrates the free flow of administrative provisions for development and those who give in to it forget the ideals of good governance and frustrate the system for their private gains.

Dike (2003) sees corruption manifesting in three different ways; political corruption which takes place at the highest levels of political authority with telling effects on decision making. It happens when public policy makers, saddled with the task of formulating, establishing and implementing decisions relating to governance on behalf of the people, are themselves corrupt. It manifests in the manipulation of public institutions and rules of procedure. Electoral corruption is the buying of votes, special favours or promises of votes, and bureaucratic corruption is the low levels or street levels corruption, which the citizen's experience in schools, hospitals, even with the citizen's interaction with the police. An example is when one obtains a business from the public sector without passing through the appropriate procedure.

Political corruption then can be said to connote any unauthorised, non-legal and unethical misuse of public position for self-benefit. The word 'political' in this context refers to public affairs including official resources, wealth and state institution. In other words, 'political' here connotes official, public (non-private) and governmental in character. Thus, the most adversely affected victims of political corruption are usually the citizens of a defined political territory and public affairs in general (Odeyemi, 2014).

The effects of corruption on a nation have also been classified into economic, social and political (Aluko, 2004). In the economic realm, corruption depletes a nation's wealth and increases the costs of goods and services. Socially, corruption discourages people to work together for a common good and encourages frustration and general apathy among the people, as well as widens the gap of social inequality between the rich and the poor. On the political side, corruption impedes democracy and the rule of law. It also results in cynicism, reduced interest in political participation and political instability (Aluko, 2014).

What the foregoing analysis imply is that while corruption may take many forms, depending on contexts and entities under study, the various manifestations are often symptoms of the same malaise, and attempts at combating one necessarily work to limit the scourge of others.

Leadership on the other hand has been severally defined such that it becomes increasingly difficult to arrive at a definite working definition. For instance, one could define it as the ability to inspire confidence and support among those whose competence and commitment determine performance. It has also been referred to as "the process of influencing the activities of an individual or group in efforts towards goal achievement in a given situation" (Alo, 2014). Leadership is an important element in the social interactions of groups whether in public or private setting, as it makes all the difference in the fortunes of any social group, be it a family unit, a business corporation or a nation (Imhonopi \& Urim, 2013; Alo, 2014). Groups need leaders and leaders need followers.

Over time, the conception of leadership has moved from an elitist activity related to power and hierarchy, essentially top-down, charismatic, and individualistic process, inbred and congenital potential possessed by a minority to a relationally dynamic activity in which people interact and attempt changes aimed at utilising their knowhow in shaping their world. Leadership is both a relation and a process. It is a relation between persons who are engaged, together, in some cooperative activity or set of activities to achieve a common goal. It is a multilevel web of social influence by which the accomplishment of an end is pursued through the influence of many people by one person (Chemers, 2002).

Leaders essentially direct the workings of the collective towards attaining a jointly shared end. It requires explicit organisational ability, strategic thinking and character laced with vision and goodwill. It is then expected that one who carries the leadership responsibility must, inter alia, possess traits of tact, vision, charisma, character and goodwill as team members expectedly ascribe leadership to individuals they trust in positively shaping the attainment of desired ends.

When leadership is discussed, a crucial aspect that is well illustrated is its political strand, by which we mean the class of people saddled with the task of conducting the operations and machineries of a political system, through the choice of policy decisions that impact on institutions and structures for a steady pursuit of the development ends of the territory. It also connotes the team of humans that runs the public affairs of a particular political territory. Public leaders abound in decision-making positions of public life. These include people who hold decision-making positions in government, and people who pursue such placements by all means possible. It also includes the elite with the ability to influence the conduct of public affairs from behind the scene. It is the totality of relations and processes that Omole (2014) refers to as "the institutional catalyst required to deliver the promises of development". 
Development and underdevelopment on the other hand can be viewed as two sides of a coin, with a movement from one necessitating moving a nation towards the other. It places attention on issues of development in the impoverished regions and countries of the world, representing a substantial size of the world's geographical divisions, and traversing considerable part of global annals. Events across the world present cases of a highly unbalanced and unequal international system where many societies are abjectly poor while some exude wealth in proportions. Across different countries of Africa, Asia and in Latin America, individuals and nations wallow in want and deprivation. This represents the development challenge.

What is however understood as development varies from scholar to scholar, practitioner to practitioner and advocate to advocate. It has been variously termed as industrialization, modernity or even westernization with modern tools, technologies and artefacts. It has also been associated with the Millennium Development Goals (MDGs), with emphasis on the eradication of poverty, hunger, mortality and diseases. Development has also been discussed in a way that constrains it to its economic strand, with emphasis on the multiplier effect of economic advancement on all other aspects.

One can posit however, that in broad terms, the totality of what constitutes development is multidimensional and multi-sectorial, spanning socio-cultural, political, economic or even human (Okeke, 2009). This had led to a variety of definitions from different scholars. W. W Rostow sees it basically as the progressive advancement from the traditional, primitive and underdeveloped society to an advanced, modern and industrial society characterised by high mass consumption of goods and services. The author listed five procedural stages that all societies desiring development must pass through, as witnessed in the counties of America and Western Europe. In other words, the development process of the impoverished nations must ape what is obtainable in the developed countries, summarised in movement across stages of Traditional, Pre-Conditions for Take-Off, Take-off, Drive to Maturity and High Mass Consumption (Rostow, 1960). Viewed similarly from an economic perspective, Hoogevelt (1978) sees development as a process of induced economic growth, of a social change in an internally stratified world.

For Almond and Powell (1966), development is to be viewed from the superstructural angle - the political which to the authors implies the gradual metamorphosis of a political system to a more ideal state dominated by vastly advanced political culture and structure, featuring "cultural secularization" (where members of the society radiate rationality, analytical mien as well as being aware and active in political activities) and "structural or role differentiation" (transformation of old functions in addition to emergence of new types of roles added with an enhanced capacity of the political system to perform conversion function, system maintenance function and adaptation function). The totality of these are crucial for state/nation-building, institutional strengthening, political participation, economic efficiency and allocation of resources in an authoritative manner. Vastly developed countries of North America and Western Europe exemplify political systems that exude these features of cultural secularization and structural differentiation (Almond and Powell, 1966).

Other scholars have viewed development from other strands. Morris (2010) sees it from the socio-cultural perspective to connote "the bundle of technological, organizational, subsistence and cultural accomplishment through which people feed, clothe, house, and reproduce themselves, and explain the world around them, and resolve disputes within their communities, and extend their powers at the expense of other communities as well as defend themselves against others' attempt to extend power".

Walter Rodney, in what was to become a seminal assertion, attempted an all-encompassing definition of development to mean:

an overall social process which is dependent upon increased capacity of members of a society to master the laws of nature (that is science) and apply such laws in the production of tools (that is technology) with which they can control their environment to meet their immediate and future needs. It then involves all segments of the society (Rodney, 1972).

From the Rodney definition, one can infer that development covers a whole range of human activity as it affects the environment, without the alienation of any segment. Development has equally been defined "as an increasing capacity to produce and build upon what was inherited, while advancing steadily" (Abdulrahman, 2012). What can be inferred from the foregoing submissions however, is that it is obvious that scholars in the field of development have no agreement on what the components of development are. It is seen variously from the economic strand, the political strand and the socio-cultural strand. The differences notwithstanding, it is indisputable that development is about progressive and transformational change. It is a complex process through which a society metamorphosis itself economically and socio-politically, in a way that manifests positively in the 
general welfare of the people. The quantitative and qualitative transformation is then manifested in different spheres of a particular human society. This desired end has been attained by such industrialised countries as the United States of America, Germany, Canada, Japan, the United Kingdom, Russia, e.t.c, while countries in Africa, parts of Asia and Latin America continue to strive to attain it.

Overtime, attention in the development field has shifted from mere development pursuit to the centrality of a level of development that is sustainable. This connotes development that "meets the needs of the present generation without compromising the ability of the future generations to meet their own needs" (Bruntland Commission, 1987). The emphasis here is to make prudent and optimal use of available resources and ensure conservation of resources and technological as well as skills transfer across generations. It is also important to widen the scope of development into the realm of national discourse. Here, Imhonopi and Urim (2010) conceives of it as:

the ability of a country to improve the social welfare of the people, namely, by providing social amenities like good education, power, housing, pipe-borne water and others. The components of national development include economic development, socio-cultural empowerment and development and how these impact on human development. Without human development, which is the development of the human capital of a nation or its citizens, national development can be thwarted or defeated. In fact, human development is one basis for judging the effectiveness of the economic development component of national development (Imhonopi \& Urim, 2013).

When viewed from the foregoing elaboration, development then is balanced when suited to meet human needs. Its central focus should be human beings who constitute the fulcrum of a nation. Any development plan without emphasis on the people then loses its usefulness and focus. Development should help to ensure that people are helped out of what Streeten (cited in Imhonopi and Urim, 2013) called "the chief evils of the world today such as malnutrition, illiteracy, disease, slums, inequality and unemployment". Development should promote functional employment and empowerment for the people and also help alleviate want and deprivation, while working to ensure the institutional structures of governance all function to the people's optimal benefits.

\section{A Trajectory of Corruption in Nigeria and Amongst Nigerians}

The totality of what is regarded as corrupt acts, by and large, is entrenched and endemic in all human political systems and governments, irrespective of the religion, continent or ethnic nationality. It is not dependent on religious beliefs and it spans political systems and affects all kinds and genders of human being alike. Whether totalitarian, democratic, leftist, rightist or monarchical system, corruption exists (Dike, 2008).

As a social malaise, it has always been part of human history, from antiquity, with cases of overt and covert corrupt acts pervading even the ancient world. Thus, corruption has been ubiquitous in complex societies from ancient Egypt, Israel, Rome, and Greece down to the present (Lipset \& Lenz 2000). Cases of corruption and widespread illegality can be said to possess global conspicuousness (Obasanjo, 1999; Kaufman et al., 2000). However, this does not imply that the extent of corruption is the same in all societies as the features are more prominent in some than others. Developing societies generally suffer more from the consequences of corrupt acts as a result of their weak institutions while it is minimal in advanced nations because of more effective and developed institutional checks (Imhonopi and Urim, 2013).

Tracing corruption to the economic division of the world across various continents, it can be asserted that there is widespread corruption in third world countries because the conditions therein are favourable for it. There are many reasons why this is so:

The motivation to earn income from among the populace in developing countries is relatively stronger; exacerbated by poverty, unemployment and low wages. In Nigeria, accountability is generally weak. Political competition and civil liberties are often restricted. Laws and principles of ethics in government are poorly developed and the legal instrument charged with enforcing them are ill- prepared (Shehu, 2006).

The foregoing assertion shows that in Nigeria, like many other developing country, cases of corrupt acts have become the rule, rather than the exception, and the mechanisms in place to curb the menace have arguably been unable to deter people from engaging in it. It can be asserted that corruption has always been an offence in Nigeria. Section 98 of the criminal code of the country refers to it as "the receiving or offering of some benefits, rewards or inducement to sway or deflect a person employed in the public service from the honest and impartial discharge of his duties". (Section 104 of the same Criminal Code; Sections 115 and 116 of the Penal Code; the 
Corrupt Practices and Other Related Offences Act, 2000; Money Laundering Prohibition Act 2004 and the Economic and Financial Crimes Commission Act 2004 further highlight corruption as an offence).

The magnitude of corruption in the country can be placed in a broader perspective when viewed from the periodic rankings of Transparency International (TI). TI is an international organisation that studies corruption amongst and within countries of the world. The organisation's Corruption Perception Index (CPI) is the most widely used indicator of corruption in political parties, police, justice systems and civil services (Ogundele \& Adetayo, 2013).

In 1996, 1997 and 2000, Nigeria's level of corruption as ranked by TI was the highest in the world. For five times, it took a second position. It took third, fourth and fifth positions once each. Its position in 2007 was ninth. It ranked sixteenth out of 180 in 2008. In 2013, the country ranked as the $34^{\text {th }}$ most corrupt of the 177 countries studied (Ogundele \& Adetayo, 2013). This was a slip from the $54^{\text {th }}$ placing the country ranked in the previous year 2012. TI's 2013 survey gave Nigeria as an example of countries where oil resources, the nation's biggest source of wealth, were only available to a very small elite.

Several studies have focused on the prevalence of corruption in Nigeria across time, with its origin traced to the colonial era. Prior to independence, the country experienced reports of official misuse of resources for private enrichment (Storey, 1953), as far back as 1954 (ACBF, 2007). Several examples can be made of claims and counter claims of corrupt behaviour that dogged the public sector, leading to the institution of a commission of inquiry to investigate allegations of abusive acts against Dr Nnamdi Azikwe, the then leader of government business and later the premier of now defunct Eastern Region of Nigeria (Imhonopi \& Urim, 2013). Dr Azikwe had been alleged by the regional House of Assembly Chief Whip of abusing his public office in moving public funds to support the African Continental Bank, a bank where he allegedly had significant personal interest. There were also reports of probe into cases of corrupt acts against ministers and other public officials in the old Western Region, set up by the military's sole administrator in 1962 which indicted most of the accused officials of abuse of their positions. Following recommendations of the prone panel, the possessions of indicted officials were confiscated and put off for sale by the government to recover parts of the losses. This was also to discourage others from engaging in such abusive acts in the future (Imhonopi \& Urim, 2013).

Ever since, the polity in Nigeria across different phases, eras and generations have been awash with cases of corrupt acts across various sectors, in various ways of manifestation. These have been identified and explained by Ndubusi (1991) to include endemic, planned and developmental corruption. Similarly, Yahaya (1993) discovered three categories in Nigeria, in which the various forms of corruption can be classified. These categories are; political corruption, corruption in the routine course of government business and corruption in the exercise of substantive government business.

- Political Corruption: This includes election and electoral fraud, rigging of election result, awards of false contracts, wealth acquisition through financial impropriety by political officer holder, misuse and abuse of political or bureaucratic office, nepotism and tribalism.

- Corruption in the routine course of Government Business: This includes bribes solicited for and paid to have compromising documents retrieve from files and for other favours, payment for letters of recommendation, kick-backs for hiring government equipment, all forms of brides, false travel documents and other claims, ghost workers and salary frauds, neglect of public service for personnel business.

- Corruption in the exercise of substantive government business: This includes false bills, court tampering, postal frauds, all form of tax frauds and auditing frauds (Yahaya, 1993).

This list is not in any way exhaustive, but does help to expose the various corrupt practices which strive in Nigerian public life. The situation is well highlighted by President Olusegun Obasanjo in his inaugural speech at the dawn of the Fourth Republic thus:

Government and all its agencies became thoroughly corrupt and reckless. Members of the public had to bribe their way through in ministries and parastatals to get attention and one government agency had to bribe another government agency to obtain the release of their statutory allocation of funds. The impact of official corruption is so rampant and has earned Nigeria a very bad image at home and abroad. Besides, it has distorted and retrogressed development (Obasanjo, 1999).

President Obasanjo's assertion is an essential summary of how corruption has ransacked all facets on national life with a former Chairman of Nigeria's Economic and Financial Crimes Commission (EFCC), Mallam Nuhu Ribadu, asserting that political leaders who held public offices from independence till the return to civil rule in 
1999 looted the commonwealth to the tune of about US \$507 billion (Igbuzor, 2008). In today's public finance analysis, this amounted to about twenty years of Nigerian national budget outlay. President Obasanjo further elaborates:

Corruption (is) the greatest single bane of our society today. . . But it must not be condoned. . . No society can achieve anything near its full potential if it allows corruption to become the full-blown cancer it has become in Nigeria. One of the greatest tragedies of military rule in recent times, is that corruption was allowed to grow unchallenged, and unchecked, even when it was glaring for everybody to see. The rules and regulations for doing official business were deliberately ignored, set aside or by-passed to facilitate corrupt practices (Obasanjo, 1999).

Allegations of corrupt acts accounted for the successive overthrows and coup-de-etat of the military years, with the displacing regime accusing the preceding regime of widespread corruption by public officials (Bassey et al., 2013). Corruption is today in the words of Okigbo (cited in Bassey et al., 2013) systemic, making it difficult for anyone who is part of the system to escape from experiencing and being a part of it. The country has thus witnessed a situation where corrupt behaviour has dogged successive Nigerian political leadership at different levels, and in varying degrees (Amaechi, 2014).

The Nigerian society has manifested this malaise in different ways, and in elaborating on these, we borrow from the work of Onimode (2000) who pinpointed six inter-related types of corrupt practices that has permeated every strata of the Nigerian society:

- Misappropriation of public funds and embezzlement;

- Looted funds and wealth kept secretly abroad;

- Money laundering including extra-legal and illegal transfer of fund across national borders by official controls over such transfers;

- Gratification involving monetary, pecuniary, material or even physical favours like sexual relationships;

- Abuse of office, including the violation of the oath of office by an incumbent, debasement of official procedures for personal financial or non-material gains and obstructing due process or rule of law for political advantage;

- Nepotism, favouritism and other forms of primordial considerations (Onimode, 2000:

32)

The foregoing assertion underscores various ways in which corrupt acts manifest in everyday life in Nigeria and among Nigerians. However, successive governments have put certain policies and institutions in place in order to reduce the menace of corruption in Nigeria. These policies include: anticorruption campaign, the Ombudsman system; system of inventory of property and assets; illegal wealth investigation system; internationalisation of corruption control; anti-corruption law; the Economic and Financial Crimes Commission (EFCC) as well as the Independent Corrupt Practices and other related offences Commission (ICPC) (Bassey et al., 2013). The Obasanjo administration of 1999 to 2007 which heralded the Fourth Republic in Nigeria was especially credited with giving the fight against corruption a serious thought with the institution of the EFCC (Amaechi, 2014). Having inherited a "polity smarting from decay as a result of long years of military rule; (in which) social infrastructure, economy, public service, rural development, etc. were all in poor state, (manifesting) in cases where there was total infrastructural decay, the economy was in shambles, inefficient and corrupt public service, and wastages in government spending" (Okoye et al., 2012), the Obasanjo administration embarked on reforms in different sectors of the economy one of which is the anti-corruption crusade.

While the various reforms of the Obasanjo years did not eradicate incidences of graft in the country, it gave a consciousness of corruption being a serious criminal offence to the minds of the citizenry. However, the marginal gains recorded in the anti-corruption crusade under Obasanjo appeared to have dwindled under succeeding administrations.

\section{The Jonathan Administration, Corruption and Governance}

The current administration of President Goodluck Jonathan in Nigeria has been variously termed as overtly aiding corruption and corrupt practices in both the public and private spheres. There have been reports of more than 5 trillion naira in public funds looted through fraud, embezzlement and theft since the president assumed office on May 6, 2010 (Ogunseye, Okpi and Baiyewu, 2012; see Punch Newspaper of November 25). There 
have also been reports of several top officials of Jonathan's administration accused of looting or misusing public funds, being spared of prosecution (Ekott and Udo, 2013).

Indeed, Aminu Tambuwal, Speaker of the Federal House of Representatives, an arm of Nigeria's bi-cameral legislature and of the same political party with the president, famously and publicly accused Jonathan of consistently displaying a "body language" that encourages corruption (Ekott \& Udo, 2013). Mr. Tambuwal said the president's penchant for duplicating committees to investigate corruption cases, rather than directing law enforcement agencies to probe them, showed Jonathan was less committed to curbing abuse of position. "By the action of setting up different committees for straightforward cases, the president's body language doesn't tend to support the fight against corruption" (Tambuwal, quoted in Ekott and Udo, 2013).

In another assessment from a public official which further underscores the level of corruption, Governor Adams Oshiomhole of Edo State in Jonathan's south-south geo-political zone, has also lamented his surprise that no one is in jail over corruption in Nigeria. According to him, "instances of corrupt practices abound, yet no one was being held answerable" (Azania, 2013). The several cases of corrupt acts under Jonathan further are well elaborated upon by Amaechi (2014) thus:

Currently in the present regime of President Goodluck Jonathan, corruption appears to have been institutionalized. A whopping sum of twenty billion dollars is alleged to have been missing. The stories of both fuel and kerosene subsidy are not anything to behold. It smears of corruption and rottenness. The aviation bulletproof saga remains unresolved. The Shell Malabu story is a macabre dance. The response of the regime to corruption is to imprison those exposing corruption. The impunity in corruption is extended to the punishment of those who fight corruption. . (Amaechi, 2014)

The several cases highlighted by Amaechi, himself a governor in the same south-south region from where the president originated, is a summary of several controversial cases in which accusations and counter-accusations of corrupt acts have dogged the Jonathan administration.

The assessment of the Jonathan administration and verdicts of corrupt acts has taken an international dimension, with several reports and opinions accusing the government of doing little to fight corruption in the polity. The United States Government in March 2013 condemned the action of the Jonathan administration in granting presidential pardon to persons who were once convicted of corrupt acts following prosecution by the EFCC. The National Council of States headed by the President had granted pardon to a former Governor of Jonathan's home state of Bayelsa, Diepreiye Alamieyeseigha, former head of the Bank of the North, Shettima Bulama and some others. In response, the U.S. Mission in Nigeria expressed its disappointment at the granting of such pardons, describing it as a setback in the war on corruption (Ibeh, 2013). Similarly, Transparency International urged the president to rescind the pardon:

This decision undermines anti-corruption efforts in Nigeria and encourages impunity. If the government is serious about uprooting public corruption, sanctions against those who betray the public trust should be strengthened, not relaxed. . President Jonathan should show that he is committed to fighting corruption and endorse the efforts of law enforcement agencies to end impunity for corrupt officials. . . Nigeria's EFCC has prosecuted and convicted a number of high-profile corrupt individuals since its inception in 2003, but most of them have escaped effective sanctions (TI, 2013).

Such acts by the Jonathan administration is symptomatic of how corruption has manifested severally in Nigeria and has impeded the nation's development. It must have also influenced several pronouncements accusing the polity of corruption-ridden. Amongst several other indicting statements, a former United States Secretary of State, Mrs Hilary Clinton accused the administration of squandering oil resources and indirectly helping corruption to fester (Ameh, 2014). The New York Times in its editorial opinion of May 62014 accused Jonathan of "leading a corrupt government that has little credibility".

\section{Leadership Crisis and Corrupt Acts in Nigeria: A Synopsis of Reinforcing Underdevelopment Challenge}

From the foregoing analysis, it is quite possible to situate the Nigerian case within a proper context and examine how and why the nation has yet to harness its huge material and human resource endowment in escaping the underdevelopment doldrums. It is also important to discuss how leadership crisis in the polity has contributed immensely to drag Nigerian into its present state of want, deprivation and hunger, where a vast majority of the citizens live below the poverty line. Overt and covert corruption in high places have contributed remarkably to 
this.

In laying a foundation for Nigeria's current state, the late renowned novelist, Chinua Achebe (1984:1), declared that the problem with the country could be traced to poor leadership:

The trouble with Nigeria is simply and squarely a failure of leadership. There is nothing basically wrong with the Nigerian character. There is nothing wrong with the Nigerian land, climate, water, air, or anything else. The Nigerian problem is the unwillingness or inability of its leaders to rise to their responsibility, to the challenge of personal example, which is the hallmark of true leadership (Achebe, 1984:1)

The foregoing Achebe assertion implies that the state of Nigeria's lacklustre level of development is as a result of the conducts and policies of successive sets of political leaders that have steered the wheel of the nation and managed public wealth since independence in 1960. This point is further alluded to by El-Rufai (2013:71) thus:

. . . corruption is really only a symptom of Nigeria's problems. The true culprit behind our country's lacklustre progress is actually much deeper and even more difficult to identify, but. . . I refer to it as disastrous political leadership and bad decision making leading to a culture of impunity (El-Rufai, 2013:71)

The viewpoint of El-Rufai buttressed several others that have linked Nigeria's current state of affairs to poor leadership and adoption of wrong-headed policies at different points in the country's history (Alo, 2014). The interrelatedness of leadership and the pursuit of development ends are captured in the thoughts of Akinrinade (2014) who opines that the three key concepts of Leadership, Governance and Development "could be likened to the Trinity concepts in the divinity, that are inextricably interwoven such that obeisance to one is genuflection to all three" The author noted that any society that is blessed with genuine and competent leadership should have good governance and sustainable development - "the Nigerian problem is the inability of its leaders to rise to their responsibilities, by showing personal examples of true leadership" (Akinrinade, 2014).

The leadership challenge in Nigeria no doubt have manifested in various ways. However, one areas in which it has left lasting impact, albeit negatively, on the nation's socio-political landscape is in unmitigated levels of corrupt acts that have impoverished the nation and its people and have left the country wallowing in abject poverty, even when the country is unarguably one of the most endowed nations of the world. In essence, over the years, corruption has become a way of doing things and has been practically institutionalized in Nigeria, buttressed by the inability of successive leaders to curtail it. One of the nation's leaders in the years immediately after independence, Maitama Sule captures the leadership challenge and related corrupt acts thus:

I say this with no apologies and it is unfortunate. We have a large chunk of irresponsible people as politicians today. What we have today in Nigeria are job seekers. They are businessmen who come to look for their daily bread; they are not politicians. They did not come to give but to take away. They did not come to lead but to loot. And they are looting us blind. Things were not like this. Things have gone so wrong that the country is in a pitiable condition (Sule, quoted in The News)

Sule's opinion underscores the extent to which public leaders have led the way in corrupt practices. While it may be posited, in agreement with Omole (2014b) that "countries over the world have at different times during their developmental journey stared at this behemoth squarely and fought it with all their might", the situation in Nigeria has been the leadership at different levels, instead of fighting it head on have competed in corruption scales. This has impeded the fight against corruption.

In effect, corruption in Nigeria has led to irrational decisions which are myopic and motivated by greed, squandering of resources on unsuitable projects, loss of confidence of the people in government and the development of cynical attitude towards leadership (Chinye, 2005). The situation has led to several ill-effects and wastage of resources in the country which Igbinovia and Aigbive (2009) summarized as resulting in infrastructure collapse, poor service delivery, poorly equipped and inadequately trained bureaucracy, manipulation of the judicial and electoral process as a result of civil service politicisation and loss of public funds running into several billions resulting in low GDP, GNP, etc.; and a grossly underdeveloped economy suffering from poor corporate governance and sharp practices exacerbated by dysfunctional supervision and regulation by relevant bodies. The effects of corrupt acts on governance and development are catastrophic. It results in less democratic government susceptible to human right abuses while disparaging equity, accountability, transparency and openness which are the hallmark of credible democratic governance. (Chinye, 2005). Corruption has equally led to a degeneration of moral values amongst Nigerians and in Nigeria with wealth 
celebrated without recourse to the source of such wealth. Unmitigated levels of corruption and leadership crisis have also manifested in the collapse of public facilities, with funds meant for social infrastructure diverted to private ends by both appointed and elected class of public officials and their cronies.

Another area in which the ill-effects of corruption and leadership incapacity have impacted negatively is the issue of insecurity which has become a big bane to governance and development in Nigeria. As Oghi (2013) has observed, where there is a high disparity level between rich and corrupt public officials on the one hand, and the common people on the other hand, there is bound to be insecurity in the society. A report by CBC News, a Canada based online media attributed the birth of the terrorist organisation, Boko Haram, to "the wide-scale kleptocracy of the Nigerian government ... accused of pilfering billions of dollars of oil revenues and having spawned a massively corrupt civil service" (Gollom, 2014). The report quoted Sarah Chayes, a senior associate at the Carnegie Endowment for International Peace, as studying the links between systemic corruption in governments around the world and the emergence of extremist insurgencies. She said all those countries, including Nigeria, were run by a kleptocratic clique. Corruption, in other words, has security implications (Gollom, 2014).

The U.S. State Department's 2013 Country Reports on Human Rights Practices found that in Nigeria, "massive widespread, and pervasive corruption affected all levels of government and the security forces. Money from oil revenue, supposed to go to programs like health and education, instead ends up in the pockets of senior government officials and civil servants" (Gollom, 2014).

Fighting corruption to its barest minimum exude possibilities of having public officials who are responsive to the needs and interests of the people thereby enhancing socioeconomic development of the society. It could also help to boost the interest of potential foreign investors, guarantee efficient delivery of public services, and promote a truly independent and prosperous country. But the situation in Nigeria has been cases of wealth looted with little to show in living conditions of the citizens, with successive set of political leaders accentuating rather than battling corrupt acts, thus exacerbating the leadership challenge further.

Tracing leadership crisis and corrupt acts in Nigeria, an analysis can be made of how leadership incapacity has led the country to its current state. Cases of corrupt acts undermined the First Republic headed by Sir Abubakar Tafawa Balewa and Dr Azikwe, the Prime Minister and President respectively. This inadvertently provided the platform for a team of young middle-rank military officers to overthrow the leadership at different levels through the bloody coup d'état of 15th January 1966 (Ogbeidi, 2012).

The succeeding General Aguiyi Thomas Ironsi government constituted a number of commissions of inquiry to probe the conducts of some public institutions and to investigate corrupt acts that dogged public administration during the Balewa era. The findings of the commissions showed that some ministers established companies and abused their positions in securing contracts. Also, cases were proven in which the ministers misappropriated public funds while showing disdain towards established processes and procedures in the award of contracts by parastatals under their Ministries (Okonkwo, 2007).

The wrongdoers of the First Republic were eventually released by the government that came into power following the Gowon coup of July 1966. This resulted in negative consequences in which new leaders initiated largely misplaced and misguided projects, with the sole aim of siphoning public wealth. This scenario clearly showed that the military usurpers were not in any way better than the displaced civilian officials. General Yakubu Gowon was in power when Nigeria amassed unprecedented proceeds from the oil boom of the 1970s, with little to show in terms of probity and accountability. By 1974, cases of unmitigated levels of corrupt acts by Gowon's military administrators in charge of the states had dominated public discourse (Ogbeidi, 2012). By July 1975, the country witnessed another coup which brought in General Murtala Ramat Mohammed into power.

The 1975 coup made attempts at stemming the tide of corrupt acts in the public service. General Murtala Mohammed led the way by publicly declaring his assets and ordering all public officials to do same. The government constituted a number of panels to investigate former leaders. By 1975, the reports of the panels resulted in the dismissal of ten out of Gowon's twelve military governors following indictment by the Federal Assets Investigation Panel. The public officials also had assets in excess of the legitimate earnings confiscated (Maduagwu, quoted in Ogbeidi, 2012).

Commissions were also set up at the state level by the newly constituted governments which led to the sack of several public officials indicted of corrupt acts. As a matter of fact, a large percentage of the officials had to refund the ill-gotten wealth into public treasury. The fight against corruption was however cut short with the assassination of General Murtala six months into his tenure. His successor, General Olusegun Obasanjo, did little to maintain the zeal of his predecessor in the war on corrupt acts, until he handed over power to a Shehu Shagari 
led democratically elected government in 1979.

Corrupt acts subsequently reared its ugly head again under the Shagari administration of the Second Republic. The administration nested unmitigated levels of public sector corruption, with the leadership showing little interest in curbing the menace. This was also because access of funds was enhanced with reports that from 1979 to 1983 when Shagari oversaw governance in the country, oil proceeds amounting to more than US \$16 billion were pillaged (Ogbeidi, 2012).

General Muhammadu Buhari emerged to orchestrate a successful palace coup that displaced Shagari's overtly corrupt government on 31st December 1983. The regime undertook the war on corruption, indiscipline as well as public conformity with decent public life and conduct as its watchword. Like the Murtala regime, the government instituted investigative tribunals to probe civilian governors and heads of government ministries during the Shagari administration. The marginal gains recorded in the attack on corrupt behaviour were however flooded with human right abuses, thus heralding public applause when General Ibrahim Babangida led another place coup to ascend the presidential mantle in August 1985.

The Babangida regime would however go down in the historical books as one which gave very overt corrupt acts "an institutional structure" in Nigeria. The rate at which corrupt behaviour blossomed and festered under Babangida was so alarming to the point that indicted public officials of previous regimes led by Murtala and Shagari emerged to retake their confiscated possessions. They also returned strategic positions in public life. The situation is well highlighted by Maduagwu thus:

Not only did the regime encourage corruption by pardoning corrupt officials convicted by his predecessors and returning their seized properties, the regime officially sanctioned corruption in the country and made it difficult to apply the only potent measures, long prison terms and seizure of ill-gotten wealth, for fighting corruption in Nigeria in the future (quoted in Ogbeidi, 2012).

The Babangida regime was halted following heightened public disapproval of his continued stay in office. He constituted and handed over power to an Interim National Government headed Chief Earnest Shonekan in August 1993. The Interim National Government was subsequently displaced by Babangida's Chief of Army Staff, General Sani Abacha in November 1993. Abacha then adopted and vastly consolidated on the corrupt acts of the Babangida years.

While General Abacha held power, corruption became completely entrenched in public sector ethos in Nigeria. Abacha, his family, friends and associates committed a level of looting never before witnessed in the country's history, with Transparency International in its Global Corruption Report of 2004 rating the regime as the fourth most corrupt in human history, embezzling public funds to the tune of US\$ 5 billion. Abacha's continued onslaught on public wealth came to a sudden end when he died in office on $8^{\text {th }}$ June, 1998. His successor, General Abdulsalami Abubakar, quickly set out to redeem the battered image of both the military institution and the Nigerian nation by handing over power to an elected civilian administration in May 1999, heralding the Fourth Republic (Ogbeidi, 2012).

The Olusegun Obasanjo administration which emerged at the dawn of the Fourth Republic in 1999 put mechanisms, structures and institutions in place to combat public and private sector graft in Nigeria. The government instituted reforms, consolidated on the country's anti-corruption laws and instituted the Independent Corrupt Practices Commission (ICPC) and the Economic and Financial Crimes Commission (EFCC) to combat corrupt acts in both the public and private sectors. This has not however stemmed the tide of corruption in the country.

A critical appraisal of the synopsis of political leaders and corrupt acts in Nigeria will buttress a clear cut relationship, with successive public officials attaining power, guarded with the intention of amassing stupendous wealth at the expense of public good and worthy service.

\section{Summary and Conclusion}

Indeed, it can be asserted that corruption has been the biggest impediment to Nigeria's socio-economic development and the wellbeing of citizens. It has become the biggest behemoth in the pursuit of sustainable growth and development in the country. Corruption has hindered sustained economic growth, inhibited foreign investments and wasted a sizeable percentage of public resources that could have been channelled towards development ends. The poor have continued to wallow within the cycle of poverty and governance crisis has become the order of the day, thus impeding democracy and democratic practise.

The country has endured failures of successive political leadership whose lust for the commonwealth had 
inevitably manifested in more misery for near powerless citizens. Since independence, successive political leadership, civilian and military alike, have terribly misappropriated the nation's resources with impunity, thereby limiting economic prosperity and human development in the country.

Embezzlement, misappropriation and monumental fraud, directly and indirectly, have come to summarise all the social ills that the Nigerian society has manifested. The vicious cycle and trend of poverty continue to fester resulting in high unemployment rate. With nepotism as the norm, mediocrity takes priority over merit, bringing about situations where the country's brightest minds continue to drift abroad in search of the proverbial greener pasture, thus depleting the human capital. All these have resulted in the country living below its huge economic potentials even the midst of substantial natural and human resources, with the life of an average Nigerian worse off when put side by side with what is obtainable in some developing countries.

By and large, high level corruption means the country continue to struggle with getting the right methods in improving on the living standard of its majorly poor and economically disadvantaged population. Public and private sector corruption is a monster that must be tamed before it grounds the country to a halt.

In conclusion, this paper has discussed leadership and corruption as it affects Nigeria's public life since the attainment of classical independence in 1960. It has been analysed how the evils of corruption and leadership crisis and failure have combined to limit the country's move towards development, the abundance of human and material resources notwithstanding. It has also talked about how successive leadership in the country have siphoned public funds into private pockets and have continually misappropriated and diverted public wealth at the expense of the vast majority of Nigerians and Nigeria. Corruption, especially when it involves the political leadership, stains good governance and limits development. It is the major obstacle to development in Nigeria and tackling it is essential to the survival and progress of Nigeria. And the struggle to tame its tide must necessarily involve all stakeholders, spearheaded by the political leadership.

\section{References}

Abdulrahman, K. (2012, May 5). Corruption as basis for Nigeria's underdevelopment, The Punch. Retrieved March 17, 2014, from http://www.punchng.com/opinion/corruption-as-basis-for-nigerias-underdevelopment

ACBF. (2007). Institutional frameworks for addressing public sector corruption in Africa: Mandate, performance, challenges \& capacity needs. Boulder, Colorado, USA: The African Capacity Building Foundation.

Achebe, C. (1984). The Trouble with Nigeria. Oxford: Heinemann Educational Publishers.

Akinrinade, S. (2014). Leadership and Governance in National Development, lecture delivered at the MBA Executive Students' Management Lecture Series of Faculty of Administration, Obafemi Awolowo University, Nigeria, May.

Almond, A. G., \& Powell, G. B. (1966). Comparative Politics: A Developmental Approach. Boston: Little Brown and Co.

Alo O. (2014). Leadership and the Challenge of National Development, lecture delivered at the Faculty of Social Sciences Annual Lecture, Obafemi Awolowo University, Ile-Ife, Nigeria, March.

Aluko, T. (2014). Welcome Address by the Dean, Faculty of Environmental Design and Management, at the $4^{\text {th }}$ Distinguished Guest Lecture, Obafemi Awolowo University, Ile-Ife, Nigeria, May.

Amaechi, R. (2014). Nigeria: The 2015 Question - The Metaphor of Change and the Politics of 2015, lecture delivered at the second conference of the People's Media Limited by the Governor, Rivers State and Chairman Nigeria Governors' Forum, Abuja, March.

Ameh, C. G. (2014, May 10). Hillary Clinton accuses Jonathan's government of squandering oil money, aiding corruption. Daily Post. Retrieved March 15, 2014, from http://dailypost.ng/2014/05/10/hillary-clinton-accuses-jonathans-government-squandering-oil-money-aidin g-corruption

Azania, J. (2013, December). Oshiomhole expresses worry over corruption. The Punch. Retrieved March 15, 2014, from http://www.punchng.com/news/oshiomhole-expresses-worry-over-corruption/

Bassey, A. O., Abia, R. P., Attah F., \& Bassey, U. A. (2013). Corruption as a Social Problem and its Implication on Nigerian Society: A Review of Anticorruption Policies. Mediterranean Journal of Social Sciences, 4(1).

Brunt Land Commission Report. (1987). Sustainable Development - Our Common Future. Oxford: Oxford University Press. 
Chemers, M. M. (2002). Cognitive, Social, and Emotional Intelligence of Transformational Leadership: Efficacy and Effectiveness. In R. E. Riggio, S. E. Murphy, \& F. J. Pirozzolo (Eds.), Multiple Intelligences and Leadership. Mahwah, New Jersey: Lawrence Erlbaum Associates.

Chinye, C.C. (2005). The Nigerian Factor. Lagos: Amazingrafolks Limited.

Dahida, D. P., \& Akangbe, O. M. (2013). Corruption as a Bane for Under-Development in Nigeria: Issues and Challenges. International Affairs and Global Strategy, 15.

Dike, V. E. (2003). Managing the challenges of corruption in Nigeria. California: Center for Social Justice and Human Development.

Dike, V. E. (2008). Corruption in Nigeria: A New Paradigm for Effective Control. Africa Economic Analysis. Retrieved March 15, from http://www.africaeconomicanalysis.org/articles/gen/corruptiondikehtm.html

Ekott, I., \& Udo, B. (2013, December 10). EXCLUSIVE: Jonathan, Alison-Madueke, Okonjo-Iweala culpable in diversion of N8 trillion oil funds. Premium Times. Retrieved March 15, 2014, from http://www.premiumtimesng.com/news/151202-exclusive-jonathan-alison-madueke-okonjo-iweala-culpabl e-in-diversion-of-n8-trillion-oil-funds.html

El-Rufai, N. A. (2013). The Accidental Public Servant. Ibadan: Safari Books Ltd.

Fagbadebo, O. (2007). Corruption, Governance and Political Instability in Nigeria. African Journal of Political Science and International Relations, 1(2): 028-037.

Gollom, M. (2014, May 9). Boko Haram formed amid Nigerian government corruption. CBC News. Retrieved June 2, 2014, from http://www.cbc.ca/m/news/\#!/content/1.2636547

Hoogevelt, A. (1978). The Sociology of Developing Societies. London: Macmillian.

Ibeh, N. (2013, March 16). U.S threatens sanctions against Nigeria over pardon for ex-convict Alamieyeseigha, Bulama. Premium Times. Retrieved March 15, 2014, from http://www.premiumtimesng.com/news/125112-u-s-threatens-sanctions-against-nigeria-overpardon-for-ex-convict-alamieyeseigha-bulama.html

Igbinovia, P. E., \& Aigbive, O. (2009). Corruption: A Bane to Efficiency and Effectiveness in the Public Service. Ekpoma: Ambrose Alli University.

Igbuzor, O. (2008). Strategies for winning the anti-corruption war in Nigeria. Abuja Nigeria: Action Aid, Briefing Paper No 2.

Imhonopi, D., \& Urim, U. M. (2013). Leadership Crisis and Corruption in the Nigerian Public Sector: An Albatross of National Development. The African Symposium, 13(1), 78-87.

Kaufman, D., Kraay, A., \& Mastruzzi, M. (2000). Governance Matters V11: Aggregate and Individual Governance Indicators for 1996-2008. World Bank Policy Research Working Paper.

Lipset, S. M., \& Lenz, G. S. (2000) Corruption, Culture, and Markets. In L. E. Harrison, \& S. P. Huntington (Eds.), Culture Matters. New York: Basic Books.

Morris, I. (2010). Social Development. Stanford: Stanford University.

Ndubusi, A. (1991). Nigeria What Hope? Enugu: Fourth Dimension Publishers.

New York Times. (2014, May 6). Nigeria's Stolen Girls. The Editorial Board. Retrieved May 8, 2014, from http://www.nytimes.com/2014/05/07/opinion/nigerias-stolen-girls.html?hp\&rref=opinion\&_r=1

Obasanjo, O. (1999). Inaugural Address at the handover ceremony to the newly elected president. Abuja, Nigeria, May 29.

Odeyemi, T. I. (2014). "Leadership, Corruption and Underdevelopment in Nigeria", Being a seminal paper delivered at the M.Sc. Class, Department of Political Science, Obafemi Awolowo University, Ile-Ife, Nigeria, May.

Ogbeidi, M. M. (2012). Political Leadership and Corruption in Nigeria Since 1960: A Socio-economic Analysis. Journal of Nigeria Studies, 1(2).

Oghi, F. E. (2013). Corruption in the Matrix of Development in Nigeria. European Scientific Journal, 9(7), 78-87.

Ogundele, K., \& Adetayo, O. (2013, December). Corruption worsening in Nigeria - TI. The Punch Retrieved 
March 17, 2014, from http://www.punchng.com/news/corruption-worsening-in-nigeria-ti

Ogunseye, T., Okpi, A., \& Baiyewu, L. (2012, November 25). N5tn stolen under Jonathan - Investigation. The $\begin{array}{lllll}\text { Punch. } & \text { Retrieved } & \text { March } & \text { 2014, } & \text { from }\end{array}$ http://www.punchng.com/news/n5tn-stolen-under-jonathan-investigation

Okeke, G. S. M. (2009). POL 326: The Politics of Development and Underdevelopment. Course Guide developed for the School of Arts and Social Sciences, National Open University of Nigeria, Lagos.

Okonkwo, R. (2007). Corruption in Nigeria: A Historical Perspective (1947-2002). African Unchained. Retrieved from http://africaunchained.blogspot.com/2007/09/corruption-in-nigeriahistorical.html

Okoye, J. C., Anazodo, R. O., Izueke, E. M., \& Eze, S. C. (2012). Monetization of Workers Fringe Benefits: The Journey so far in Nigeria Federal Civil Service. Public Administration Research, 1(1), 50-60. http://dx.doi.org/10.5539/par.v1n1p50

Omole, I. B. (2014a). Welcome Address delivered by the Vice-Chancellor, Obafemi Awolowo University, at the Annual Faculty of Social Sciences Lecture Series, OAU, Ile-Ife, Nigeria, March 13.

Omole, I. B. (2014b). Address delivered by the Vice-Chancellor, at the Faculty of Environmental Design and Management $4^{\text {th }}$ Distinguished Guest Lecture, Obafemi Awolowo University, Ile-Ife, Nigeria, May.

Onimode, B. (2000). Overview of Corruption and Organised Crime in Nigeria. In Lame, \& Odekunle (Eds.), Fighting Corruption and Organised Crime in Nigeria: Challenges for the New Millenium. Ibadan: Spectrum Books.

Ovienloba, A. A. (2007). The weeping child. New York: Primus International Network for Education and Developments.

Rodney, W. (1972). How Europe Underdeveloped Africa. London: Bogle-L' Overtures Publications.

Rostow, W. W. (1960). The Stages of Economic Growth: A Non-Communist Manifesto. Cambridge: Cambridge Press.

Shehu, A. Y. (2006). Recovering the Proceeds of Corruption: The Challenges for Developing Countries. Nigeria Journal of Economic and Financial Crimes, 1(1).

Storey, B. (1953). Report of the Commission of Inquiry into the Administration of Lagos Town Council. Lagos: Government Printer.

Sule, M. (2010, August 02). Nigeria is in a Mess. The News, p.23.

Transparency International. (2004). Introduction to Political Corruption. Global Corruption Report, January.

Transparency International. (2013). Transparency International Calls on Nigerian President to Rescind Controversial Pardon of Corrupt Politician. Retrieved March 15, 2014, from http://www.transparency.org/news/pressrelease/20130314_transparency_international_calls_on_nigerian_pr esident_to_rescindon

World Bank. (1999). The Fight against Corruption: A World Bank Perspective. Workshop on Transparency and Governance, organized as part of the Consultative Group Meeting for the Reconstruction and Transformation of Central America, May 25-28, Stockholm, Sweden.

Yagboyaju, D. A. (2011). Corruption, Democracy and Good Governance. In O. A. Bamisaye, \& O. Awofeso (Eds.), Democracy and Democratic Practise in Nigeria: Issues, Challenges and Prospects (pp. 142-154). Lagos-Nigeria: MacGrace Publishers.

Yahaya I., (1993). The Economic Crisis, Resources Scarcity and Decline in Ethical Standard in Public Agencies. In Olowu (Ed.), Ethics and Accountability in African Public Service, Ethiopia: A. A. PAM.

\section{Copyrights}

Copyright for this article is retained by the author(s), with first publication rights granted to the journal.

This is an open-access article distributed under the terms and conditions of the Creative Commons Attribution license (http://creativecommons.org/licenses/by/3.0/). 